\title{
Comportamento ingestivo de ovinos alimentados com silagens de capim- elefante contendo casca de café, farelo de cacau ou farelo de mandioca ${ }^{1}$
}

\section{Aureliano José Vieira Pires ${ }^{2}$, Gleidson Giordano Pinto de Carvalho ${ }^{3}$, Rasmo Garcia ${ }^{4}$, José Nobre de Carvalho Junior ${ }^{5}$, Leandro Sampaio Oliveira Ribeiro ${ }^{6}$, Daiane Maria Trindade Chagas ${ }^{7}$}

${ }^{1}$ Projeto financiado pelo CNPq.

${ }^{2}$ DTRA, UESB, Itapetinga, BA. Av. das Palmeiras, 491, Bairro Morumbi, CEP: 45.700-000, Itapetinga-BA. Pesquisador do CNPq.

${ }^{3}$ Doutorando em Zootecnia, UFV, Viçosa, MG. Bolsista do CNPq.

${ }^{4}$ DZO, UFV, Viçosa, MG. Pesquisador do CNPq.

${ }^{5}$ Mestrando em Zootecnia, UESB, Itapetinga, $B A$.

6 Graduando em Zootecnia, UESB, Itapetinga, BA. Bolsista de Iniciação Científica do CNPq.

7 Graduanda em Zootecnia, UESB, Itapetinga, BA. Bolsista de Iniciação Científica da FAPESB.

RESUMO - Um experimento foi conduzido para avaliar o comportamento ingestivo de ovinos alimentados com dietas contendo silagem de capim-elefante com diversos aditivos. Foram utilizados 20 ovinos machos, não-castrados, em um delineamento inteiramente casualizado, com 4 tratamentos e 5 repetições. Os animais receberam dietas com média de $11 \%$ de proteína, compostas de $60 \%$ de volumoso e $40 \%$ de concentrado, com base na matéria seca (MS). Como volumoso, utilizou-se silagem de capim-elefante sem aditivo ou com $15 \%$ de casca de café, farelo de cacau ou farelo de mandioca, misturados ao capim-elefante no momento da ensilagem, com base na matéria natural (peso/peso). As variáveis comportamentais foram obtidas a cada dez minutos, durante 24 horas de observação. Os tempos despendidos em alimentação e ruminação foram semelhantes entre as silagens utilizadas nas dietas. Contudo, os animais que consumiram silagem de capim-elefante com farelo de mandioca apresentaram maior tempo de ócio. O consumo de matéria seca e as eficiências de alimentação (g de MS e de FDN/hora) e ruminação (g MS/hora) foram maiores nos animais alimentados com a silagem contendo $15 \%$ farelo de mandioca, o que indica que esse subproduto é um bom aditivo para utilização na ensilagem de capim-elefante. A inclusão de farelo de mandioca na ensilagem de capim-elefante melhora alguns parâmetros do comportamento ingestivo.

Palavras-chave: alimentação, consumo, ruminação, subprodutos

\section{Ingestive behavior of sheep fed elephant grass silages with the addition of coffee hulls, cocoa meal or cassava meal}

\begin{abstract}
The experiment was carried out to evaluate the ingestive behavior of sheep fed diets containing elephant grass silage with different additives. Twenty sheep non-castrated male kids were used in a randomized complete design, with four treatments and five replications. The treatments were: elephant grass silage (control); elephant grass silage $(75 \%)+$ coffee hulls $(15 \%)$; elephant grass silage $(75 \%)+$ cocoa meal $(15 \%)$ and elephant grass silage $(75 \%)+$ cassava meal $(15 \%)$. The additives were added at ensilage moment was realized in natural matter basis (weight/weight). The animals received diets with $11 \%$ protein in $60 \%$ forage and $40 \%$ concentrate proportion, on dry matter basis. The behavior variables were obtained every ten minutes during 24 hours of observation. The time spent feeding and ruminating was similar for the different silages. However, the animals that consumed diets with elephant grass silage with the addition of cassava meal showed higher idle time. The dry matter intake and the feeding ( $\mathrm{g}$ of DM and NDF/h) and ruminating (g DM/h) efficiency were higher for diets with elephant grass silage with addition of $15 \%$ cassava meal, that was shown to be a good additive for use in elephant grass ensilage. The inclusion of cassava meal positively affected some parameters of ingestive behavior.
\end{abstract}

Key Words: by-products, feeding, intake, rumination

\section{Introdução}

Entre as alternativas alimentares com potencial para suprir a demanda de nutrientes dos animais no período crítico do ano, a produção de silagem é uma opção tecnicamente viável e muito empregada pelos produtores em geral. Gramíneas tropicais têm sido muito utilizadas com esta finalidade, e o capim-elefante é uma das forrageiras com 
melhores características para ensilagem, por apresentar características como alta produtividade, elevado número de variedades, grande adaptabilidade, facilidade de cultivo, boa aceitabilidade pelos animais e, quando novo, bom valor nutritivo (Evangelista \& Lima, 2002).

Apesar dessas características que favorecem a produção de silagem, o capim-elefante possui baixo teor de carboidratos solúveis, fração importante na redução do pH após o fechamento do silo, pois propicia condições adequadas para produção de ácido lático para boa preservação da massa ensilada. De acordo com Bernardino et al. (2005), a ensilagem de gramíneas com baixo teor de carboidratos solúveis e elevada umidade favorece as perdas durante as fases do processo e propicia o desenvolvimento de bactérias do gênero Clostridium, favorecidas pela baixa produção de ácido lático.

A adição de subprodutos, como polpa cítrica (Rodrigues et al., 2005), resíduos da produção do suco de caju (Ferreira et al., 2004) e farelo de mandioca (Ferrari Jr. \& Lavezzo, 2001), no momento da ensilagem de capim-elefante tem propiciado produção de silagens de boa qualidade, com adequadas características químicas e fermentativas.

Estudos visando medir o impacto da utilização do farelo de cacau, da casca de café e do farelo de mandioca na ensilagem de capim-elefante para ruminantes são escassos. Na maioria das pesquisas, o objetivo principal é estudar a utilização desses aditivos em substituição a parte do concentrado ou do volumoso (Carvalho et al., 2006; Teixeira et al., 2007). Assim, objetivou-se com este trabalho avaliar o comportamento ingestivo de ovinos alimentados com dietas contendo silagem de capim-elefante (Pennisetum purpureum) com casca de café, farelo de cacau ou farelo de mandioca.

\section{Material e Métodos}

O trabalho foi desenvolvido no Setor de Ovinocultura e no Laboratório de Forragicultura e Pastagem da Universidade Estadual do Sudoeste da Bahia, UESB, Campus Juvino Oliveira, Itapetinga, Bahia.

Foi utilizado delineamento inteiramente ao acaso, com quatro tratamentos e cinco repetições. Na ensilagem, utilizou-se capim-elefante (Pennisetum purpureum, Schum. cv. Napier) proveniente de capineira já estabelecida, colhido quando apresentava média de 1,8 $\mathrm{m}$ de altura, após 80 dias de rebrota, e picado em partículas de aproximadamente $2 \mathrm{~cm}$ em máquina ensiladeira acoplada a um trator. $\mathrm{O}$ material foi ensilado sem aditivo (controle) ou com casca de café, farelo de cacau ou farelo de mandioca.
Todos os aditivos foram adicionados à forragem recémpicada no nível de $15 \%$ com base na matéria natural (peso/ peso), correspondendo a 35,9; 34,9 e 35,6\% com base na matéria seca (MS), respectivamente, para casca de café, farelo de cacau e farelo de mandioca. As pequenas diferenças nas proporções dos aditivos na base da MS da silagem estão relacionadas aos teores de MS, que diferem entre os aditivos. Como silos, utilizaram-se tambores de metal com volume de 200 litros, adotando-se densidade de $450 \mathrm{~kg} / \mathrm{m}^{3}$, ou seja, $90 \mathrm{~kg}$ da mistura fresca por tambor. Os silos cheios foram vedados com lona plástica e, após 60 dias de armazenamento, foram abertos para coleta de amostras, que foram pré-secas em estufa de ventilação forçada a $60^{\circ} \mathrm{C}$, durante 72 horas, e processadas em moinho tipo Willey utilizando-se peneira com crivos de $1 \mathrm{~mm}$.

As análises para determinação dos teores de matéria seca (MS), matéria orgânica (MO), nitrogênio total (NT), extrato etéreo (EE), fibra em detergente neutro (FDN), fibra em detergente ácido (FDA); e os teores de nitrogênio insolúvel em detergente neutro (NIDN) e nitrogênio insolúvel em detergente ácido (NIDA), expressos como porcentagem do nitrogênio total (NT) foram realizadas segundo procedimentos descritos por Silva \& Queiroz (2002) (Tabela 1). O teor de proteína bruta (PB) foi obtido multiplicando-se o nitrogênio total pelo fator 6,25 e o teor de carboidratos totais (CT) foi calculado segundo equações propostas por Sniffen et al. (1992).

$$
\mathrm{CT}=100-(\% \mathrm{~PB}+\% \mathrm{EE}+\% \text { Cinzas })
$$

Os teores de carboidratos não-fibrosos (CNF) foram estimados pela equação abaixo:

$$
\mathrm{CNF}=\mathrm{CT}-\mathrm{FDN}_{\mathrm{cp}} \text {. }
$$

Os teores de nutrientes digestíveis totais estimados $\left(\mathrm{NDT}_{\mathrm{EST}}\right)$ dos alimentos, das rações concentradas e das dietas totais foram calculados conforme equações descritas pelo NRC (2001). Para o cálculo do NDT $_{\text {EST }}$ (do volumoso e dos aditivos), foi utilizada a equação abaixo:

$\mathrm{NDT}_{\mathrm{EST}}=0,98\left[100-\left(\% \mathrm{FDN}_{\mathrm{p}}+\% \mathrm{~PB}+\% \mathrm{EE}+\right.\right.$ $\%$ cinza $) \times \mathrm{PF}]+\mathrm{PB} \times \exp [-1,2 \times(\mathrm{PIDA} / \mathrm{PB})]+2,25 \times(\mathrm{EE}-1)$ $+0,75 \times\left(\mathrm{FDN}_{\mathrm{p}}-\right.$ Lignina $) \times\left[1-\left(\text { Lignina } / \mathrm{FDN}_{\mathrm{p}}\right)^{0,667}\right]-7$

Para o cálculo do NDT $_{\text {EST }}$ das rações concentradas, a seguinte equação:

$\mathrm{NDT}_{\mathrm{EST}}=0,98\left[100-\left(\% \mathrm{FDN}_{\mathrm{p}}+\% \mathrm{~PB}+\% \mathrm{EE}+\%\right.\right.$ cinza $) \times$ $\mathrm{PF}]+\mathrm{PB} \times \exp [-0,4 \times(\mathrm{PIDA} / \mathrm{PB})]+2,25 \times(\mathrm{EE}-1)+0,75$

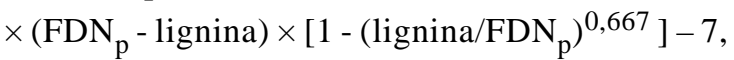
em que: FDN $_{p}=$ FDN - PIDN (PIDN $=$ nitrogênio insolúvel em detergente neutro $\times 6,25) ; \mathrm{PF}=$ efeito do processamento físico na digestibilidade dos carboidratos não-fibrosos; PIDA = nitrogênio insolúvel em detergente ácido $\times 6,25$

Para valores de $\mathrm{EE}<1$, na equação $(\mathrm{EE}-1)=0$. 
Tabela 1 - Composição química dos ingredientes das dietas experimentais, \%MS

\begin{tabular}{|c|c|c|c|c|c|c|}
\hline Item $^{1}$ & Milho moído & Farelo de soja & Casca de café & Farelo de cacau & Farelo de mandioca & Capim-elefante \\
\hline Matéria seca & 86,5 & 88,1 & 89,8 & 86,0 & 88,8 & 28,3 \\
\hline Matéria orgânica & 98,4 & 93,4 & 94,4 & 91,2 & 98,5 & 94,0 \\
\hline Matéria mineral & 1,6 & 6,6 & 5,6 & 8,8 & 1,5 & 6,0 \\
\hline Proteína bruta & 9,0 & 46,7 & 7,2 & 15,0 & 2,4 & 5,9 \\
\hline Extrato etéreo & 2,8 & 2,4 & 0,8 & 2,6 & 0,8 & 2,3 \\
\hline Fibra em detergente neutro & 14,0 & 11,5 & 73,5 & 45,7 & 11,3 & 72,7 \\
\hline Fibra em detergente ácido & 3,0 & 6,9 & 57,7 & 33,8 & 6,6 & 43,0 \\
\hline Hemicelulose & 11,0 & 4,6 & 15,8 & 11,9 & 4,7 & 29,8 \\
\hline Celulose & 2,6 & 6,8 & 41,6 & 17,8 & 4,5 & 36,3 \\
\hline Lignina & 0,4 & 0,1 & 16,1 & 15,6 & 1,0 & 5,4 \\
\hline Carboidratos totais & 86,6 & 44,3 & 86,4 & 73,6 & 95,2 & 85,8 \\
\hline Carbohidratos não-fibrosos & 75,5 & 34,3 & 18,3 & 39,6 & 92,4 & 17,1 \\
\hline NIDN/NT & 18,0 & 1,0 & 52,3 & 44,2 & 12,5 & 22,2 \\
\hline NIDA/NT & 10,1 & 0,7 & 38,6 & 39,7 & 12,5 & 6,0 \\
\hline Nutrientes digestíveis totais 1 & 87,4 & 88,3 & 27,8 & 44,2 & 83,9 & 55,8 \\
\hline
\end{tabular}

NIDN: nitrogênio insolúvel em detergente neutro (porcentagem do nitrogênio total); NIDA: nitrogênio insolúvel em detergente ácido (porcentagem do nitrogênio total); ${ }^{1}$ Estimados segundo o NRC (2001).

Transcorridos 60 dias após a ensilagem, os silos foram abertos e a silagem foi fornecida a 20 ovinos da raça Santa Inês, machos, não-castrados, com 5 meses de idade e $22,3+3,2 \mathrm{~kg}$ de peso corporal. Os animais foram mantidos em baias individuais, de $1,3 \times 0,65 \mathrm{~m}\left(0,84 \mathrm{~m}^{2}\right)$, com piso ripado de madeira, contendo bebedouros e comedouros individuais, por 77 dias - 14 dias de adaptação e três períodos de 21 dias para coleta de dados. O comportamento alimentar dos animais foi determinado nos dois últimos dias de cada período experimental, pela quantificação dos intervalos de tempo durante 24 horas/dia (Fischer, 1996). Ao início do experimento, os animais foram vermifugados, pesados, identificados com brincos numerados e sorteados, ao acaso, para os devidos tratamentos.

Os animais receberam dietas contendo $60 \%$ de silagem de capim-elefante e $40 \%$ de concentrado na matéria seca (Tabela 2).

As dietas foram formuladas com milho, farelo de soja e mistura mineral para serem isoproteicas e apresentaram média de $11 \%$ de proteína bruta (Tabela 3 ). A mistura entre o volumoso e o concentrado foi realizada no momento do fornecimento da alimentação. Os animais foram alimentados à vontade, às $7 \mathrm{~h}$ e às $16 \mathrm{~h}$, admitindo-se $10 \%$ de sobras.

No registro do tempo despendido em alimentação, ruminação e ócio, adotou-se a observação visual dos animais a cada dez minutos, durante 24 horas, feita por observadores treinados em sistema de revezamento, posicionados estrategicamente de forma a não incomodar os animais. No mesmo dia foi realizada a contagem do número de mastigações merícicas ( $\mathrm{n}^{\mathrm{O}} /$ bolo) e do tempo despendido na ruminação de cada bolo (seg/bolo), com a utilização de cronômetros digitais. Para obtenção das médias das mastigações e do tempo, foram feitas as observações de três bolos ruminais em três períodos diferentes do dia (10-12, 14-16 e 18-20 horas). Foram computados o tempo e o número de mastigações para cada bolo ruminal por animal.

As variáveis g de MS e de FDN/bolo foram obtidas dividindo-se o consumo médio de cada fração individual-

Tabela 2 - Composição percentual dos ingredientes nas dietas experimentais, com base na matéria seca

\begin{tabular}{|c|c|c|c|c|}
\hline \multirow[b]{2}{*}{ Alimento } & \multicolumn{4}{|c|}{ Silagem de capim-elefante } \\
\hline & Sem aditivo & $15 \%$ casca de café & $15 \%$ farelo de cacau & $15 \%$ farelo de mandioca \\
\hline \multicolumn{5}{|l|}{ Volumoso } \\
\hline Silagem de capim-elefante & 60,0 & 38,5 & 39,1 & 38,6 \\
\hline Casca de café & 0,0 & 21,5 & 0,0 & 0,0 \\
\hline Farelo de cacau & 0,0 & 0,0 & 20,9 & 0,0 \\
\hline Farelo de mandioca & 0,0 & 0,0 & 0,0 & 21,4 \\
\hline \multicolumn{5}{|l|}{ Concentrado } \\
\hline Milho moído & 25,0 & 27,0 & 27,5 & 24,5 \\
\hline Farelo de soja & 12,0 & 10,0 & 9,5 & 12,5 \\
\hline Mistura mineral & 3,0 & 3,0 & 3,0 & 3,0 \\
\hline Total & 100 & 100 & 100 & 100 \\
\hline
\end{tabular}


Tabela 3 - Composição química dos volumosos e das dietas experimentais, com base na matéria seca

\begin{tabular}{|c|c|c|c|c|}
\hline \multirow[b]{2}{*}{ Item } & \multicolumn{4}{|c|}{ Silagem de capim-elefante } \\
\hline & Sem aditivo & $15 \%$ casca de café & $15 \%$ farelo de cacau & $15 \%$ farelo de mandioca \\
\hline \multicolumn{5}{|l|}{ Nutrientes no volumoso $(\%)^{1}$} \\
\hline Matéria seca & 31,4 & 34,7 & 35,1 & 35,4 \\
\hline Proteína bruta & 4,5 & 5,8 & 7,8 & 4,5 \\
\hline Extrato etéreo & 3,3 & 3,2 & 4,5 & 2,6 \\
\hline Fibra em detergente neutro & 78,9 & 79,0 & 70,8 & 65,7 \\
\hline Fibra em detergente ácido & 46,7 & 52,1 & 45,1 & 34,9 \\
\hline Carboidratos totais & 85,9 & 84,4 & 81,1 & 87,3 \\
\hline Carboidratos não-fibrosos & 10,8 & 10,7 & 16,8 & 26,1 \\
\hline $\mathrm{PIDN}^{2}$ & 22,8 & 38,6 & 44,2 & 27,2 \\
\hline NDT estimado ${ }^{3}$ & 49,1 & 40,3 & 42,6 & 58,8 \\
\hline \multicolumn{5}{|l|}{ Nutrientes na dieta $(\%)^{1}$} \\
\hline Matéria seca & 54,0 & 56,1 & 56,3 & 56,2 \\
\hline Proteína bruta & 10,7 & 10,4 & 11,9 & 11,1 \\
\hline Extrato etéreo & 3,1 & 3,2 & 3,4 & 2,9 \\
\hline Fibra em detergente neutro & 52,3 & 52,8 & 47,7 & 44,9 \\
\hline Fibra em detergente ácido & 32,3 & 34,5 & 29,6 & 24,8 \\
\hline Carboidratos totais & 78,5 & 79,0 & 76,6 & 78,7 \\
\hline Carboidratos não-fibrosos & 30,0 & 31,5 & 35,3 & 39,2 \\
\hline $\mathrm{PIDN}^{2}$ & 16,3 & 26,1 & 29,5 & 18,5 \\
\hline $\mathrm{NDT}^{3}$ & 64,6 & 59,4 & 60,8 & 70,6 \\
\hline
\end{tabular}

${ }^{1}$ Dados obtidos por meio de análise química.

${ }^{2}$ Proteína insolúvel em detergente neutro/percentual da proteína bruta.

${ }^{3}$ Nutrientes digestíveis totais estimado (NRC, 2001).

mente pelo número de bolos ruminados por dia (em 24 horas). Para obtenção do número de bolos diários, procedeu-se à divisão do tempo total de ruminação pelo tempo médio gasto para ruminar cada bolo, descrito anteriormente. A eficiência de alimentação e ruminação, expressa em $g$ de MS/hora e g de FDN/hora, foi obtida mediante a divisão do consumo médio diário de MS e FDN pelo tempo total despendido em alimentação e/ou ruminação em 24 horas, respectivamente. Essas e outras variáveis obtidas neste experimento, como o número de bolos ruminais por dia, o tempo de mastigação total e o número de mastigações merícicas por dia, foram obtidas conforme metodologias descritas por Bürger et al. (2000) e Polli et al. (1996).

Durante a coleta de dados, na observação noturna dos animais, o ambiente foi mantido com iluminação artificial.

Os resultados foram submetidos à análise de variância e ao teste de Tukey, adotando-se o nível de significância de 5\%, utilizando-se o Sistema de Análises Estatísticas e Genéticas - SAEG (Ribeiro Jr., 2001), segundo o modelo experimental:

$$
\mathrm{Y}_{i j}=\mu+T_{i}+\sum_{i j}
$$

em que $\mathrm{Y}_{i j}=$ observação na unidade experimental que recebeu o i-ésimo tratamento na j-ésima repetição; $\mu=$ média geral comum a todas as observações; $T_{i}=$ efeito do i-ésimo tratamento na variável-dependente $\mathrm{Y} ; \Sigma_{i j}=$ erro aleatório associado à cada observação.

\section{Resultados e Discussão}

O consumo de matéria seca em 24 horas (CMS, $\mathrm{kg}$ ) foi significativo $(\mathrm{P}<0,05)$ e o valor foi maior para os animais que receberam a silagem com farelo de mandioca (Tabela 4). Os animais que receberam as silagens com casca de café e farelo de cacau apresentaram consumo de matéria seca semelhante $(\mathrm{P}>0,05)$ ao daqueles que consumiram a silagem com farelo de mandioca. Os maiores consumos de MS verificados para as silagens com os subprodutos indicam maior valor alimentício dessas silagens em relação àquela sem aditivo. $\mathrm{O}$ consumo de FDN diário foi semelhante $(\mathrm{P}>0,05)$ entre as dietas, com valor médio de $0,40 \mathrm{~kg} /$ dia.

As diferenças nos consumos de matéria seca não afetaram as atividades comportamentais, à exceção do tempo de ócio, que foi maior $(\mathrm{P}<0,05)$ nos animais alimentados com as silagens com aditivos. Os resultados verificados neste estudo estão de acordo com os observados por Carvalho et al. (2006), que avaliaram o comportamento de ovinos recebendo $40 \%$ de farelo de cacau ou torta de dendê no concentrado em dieta com relação volumoso: concentrado 60:40 e observaram variação significativa no 
consumo de matéria seca e nenhuma alteração nos tempos de alimentação e ruminação.

O número de bolos ruminados ( $\mathrm{n}$ \%/dia) e o tempo de mastigações/bolo (seg) também não foram afetados pelo uso dos aditivos na ensilagem. $\mathrm{O}$ valor médio obtido neste estudo para o número de bolos foi de 613,5 , enquanto, no estudo realizado por Carvalho et al. (2006), foi de 839,4. Os teores de FDN das dietas podem explicar as diferenças no número de bolos. Contudo, o tempo de mastigações/bolo, de 47,7 segundos, foi próximo do valor encontrado por Carvalho et al. (2006), de 46,7. É possível que a semelhança nesta variável entre os experimentos esteja relacionada ao diâmetro das partículas das silagens e da forrageira utilizada - capim-elefante em ambos os experimentos.

A eficiência de alimentação (g MS e FDN/hora), assim como a eficiência de ruminação (g MS/hora), foi maior $(\mathrm{P}<0,05)$ nas silagens com os subprodutos (Tabela 5), sobretudo naquela com farelo de mandioca. Isso ocorreu em resposta aos maiores consumos de matéria seca observados para essas dietas (Tabela 4).

O número de mastigações merícicas (horas/dia) foi menor $(\mathrm{P}<0,05)$ para silagens produzidas com farelo de mandioca, farelo de cacau e casca de café. A diferença encontrada, principalmente para a silagem contendo farelo de mandioca e a sem aditivo, se deve ao efeito verificado para o tempo despendido em ócio, que foi maior nos animais que consumiram a silagem com farelo de mandioca. Por outro lado, o número de mastigações por bolo e por dia não foi afetado $(\mathrm{P}>0,05)$ pela adição dos subprodutos. $\mathrm{O}$ mesmo ocorreu com os períodos de refeição, ruminação e ócio (n-/dia), que não foram alterados pela adição dos subprodutos à ensilagem (Tabela 5). O fato de as dietas terem sido balanceadas para serem isoproteicas - apresentaram valor médio de $11 \%$ de PB - e foram fornecidas simultaneamente

Tabela 4 - Comportamento ingestivo de ovinos mantidos com dietas contendo capim-elefante ensilado com diversos aditivos

\begin{tabular}{|c|c|c|c|c|c|c|}
\hline \multirow[t]{2}{*}{ Item } & \multicolumn{4}{|c|}{ Silagem de capim-elefante } & \multirow[t]{2}{*}{$\mathrm{CV}(\%)$} & \multirow[t]{2}{*}{ Valor-P } \\
\hline & Sem aditivo & $15 \%$ casca de café & $15 \%$ farelo de cacau & $15 \%$ farelo de mandioca & & \\
\hline Consumo de MS em 24 h (kg) & $0,76 \mathrm{~b}$ & $0,88 \mathrm{ab}$ & $0,96 \mathrm{ab}$ & $1,00 \mathrm{a}$ & 12,1 & 0,01653 \\
\hline Consumo de FDN em 24 h (kg) & 0,37 & 0,41 & 0,43 & 0,40 & 11,9 & 0,27332 \\
\hline Alimentação (min) & 346,0 & 316,0 & 318,0 & 264,0 & 14,3 & 0,06394 \\
\hline Ruminação (min) & 520,0 & 468,0 & 486,0 & 444,0 & 12,7 & 0,28417 \\
\hline Ócio $(\min )$ & $574,0 \mathrm{~b}$ & $656,0 \mathrm{ab}$ & $636,0 \mathrm{ab}$ & $732,0 \mathrm{a}$ & 10,3 & 0,01470 \\
\hline Bolos ruminados ( $\mathrm{n}$ o/dia) & 640,3 & 665,5 & 606,1 & 542,0 & 17,0 & 0,30501 \\
\hline Tempo de mastigações/bolo (seg) & 49,6 & 43,0 & 48,6 & 49,4 & 14,8 & $* * * * * * *$ \\
\hline
\end{tabular}

Médias seguidas de letras iguais, na linha, não diferem entre si pelo teste Tukey a $5 \%$ de probabilidade.

$\mathrm{CV}=$ coeficiente de variação; SA: sem aditivo; $15 \%$ CC: com $15 \%$ de caca de café; $15 \%$ FC: com $15 \%$ de farelo de cacau; $15 \%$ FM: com $15 \%$ de farelo de mandioca.

Tabela 5 - Eficiência de alimentação e ruminação (g MS e FDN/hora), mastigações merícicas e número de períodos de refeição, ruminação e ócio (no/dia) em ovinos mantidos com dietas contendo capim-elefante ensilado com diversos aditivos

\begin{tabular}{|c|c|c|c|c|c|c|}
\hline \multirow[t]{2}{*}{ Item } & \multicolumn{4}{|c|}{ Silagem de capim-elefante } & \multirow[t]{2}{*}{$\mathrm{CV}(\%)$} & \multirow[t]{2}{*}{ Valor-P } \\
\hline & Sem aditivo & $15 \%$ casca de café & $15 \%$ farelo de cacau & $15 \%$ farelo de mandioca & & \\
\hline \multicolumn{7}{|c|}{ Eficiência de alimentação (g MS e FDN/hora) } \\
\hline Matéria seca & $132,6 \mathrm{~b}$ & $169,6 \mathrm{~b}$ & $181,8 \mathrm{ab}$ & $232,8 \mathrm{a}$ & 16,9 & 0,00085 \\
\hline Fibra em detergente neutro & $64,1 \mathrm{~b}$ & $78,9 \mathrm{ab}$ & $81,6 a b$ & $94,2 \mathrm{a}$ & 16,3 & 0,02048 \\
\hline \multicolumn{7}{|c|}{ Eficiência de ruminação (g MS e FDN/hora) } \\
\hline \multicolumn{7}{|c|}{ Mastigações merícicas } \\
\hline Horas/dia & $14,4 \mathrm{a}$ & $13,1 \mathrm{ab}$ & $13,4 \mathrm{ab}$ & $11,8 \mathrm{~b}$ & 8,4 & 0,01470 \\
\hline №/bolo & 74,8 & 66,8 & 81,6 & 72,4 & 13,5 & 0,17060 \\
\hline No/dia & 47336,3 & 43841,7 & 48946,4 & 39091,9 & 14,6 & 0,12486 \\
\hline
\end{tabular}

Médias seguidas de letras iguais, na linha, não diferem entre si pelo teste Tukey a 5\% de probabilidade.

$\mathrm{CV}=$ coeficiente de variação. 
todas no mesmo horário pode ter contribuído para que os períodos das atividades não fossem diferentes. Além disso, os animais utilizados no experimento foram bastante homogêneos, fato que pode ter contribuído para esses resultados. O mesmo não aconteceu para os períodos de refeição, ruminação e ócio expressos em minutos, uma vez que houve diferença $(\mathrm{P}<0,05)$ no tempo gasto por período de refeição e o maior valor foi observado para a dieta sem aditivo, em decorrência do menor consumo de matéria seca.

Os resultados observados neste estudo estão de acordo com os apresentados por Carvalho et al. (2007), que estudaram o comportamento de ovinos em confinamento alimentados com dietas contendo capim-elefante amonizado ou não com $5 \%$ de ureia e relataram que a inclusão de $40 \%$ de farelo de cacau ou torta de dendê no concentrado também não ocasionou diferenças nos períodos de alimentação, ruminação e ócio ( $\mathrm{n} \%$ dia) entre as dietas.

Os consumos de MS e de FDN ( $\mathrm{min} / \mathrm{kg}$ ) diferiram entre as dietas $(\mathrm{P}<0,05)$, com valor médio, respectivamente, de 266,0 e $657,1 \mathrm{~min} / \mathrm{kg}$ nos animais que foram alimentados com dietas contendo a silagem de capim-elefante com farelo de mandioca (Tabela 6). Apesar de estatisticamente semelhantes $(\mathrm{P}>0,05)$, o consumo das silagens com casca de café e farelo de cacau apresentaram maiores valores absolutos em relação àquela com farelo de mandioca. Os menores valores de consumo de MS e FDN ( $\mathrm{min} / \mathrm{kg}$ ) na dieta com farelo de mandioca podem estar relacionados à presença de fonte de carboidrato de rápida fermentação ruminal neste aditivo, que acarreta menor necessidade de tempo entre os animais para ingerir a mesma quantidade de nutrientes.

Para a ruminação expressa em g de MS e de FDN/bolo, verificou-se efeito significativo $(\mathrm{P}<0,05)$ dos aditivos. Os maiores valores foram observados para a silagem com farelo de mandioca, como reflexo do maior consumo de nutrientes observado para essa silagem (Tabela 4). A maior eficiência em ruminação nos animais alimentados com silagem com farelo de mandioca (Tabela 5) resultou em menor tempo de ruminação, $\mathrm{min} / \mathrm{kg}$ de MS (Tabela 6). Os menores valores para o tempo de mastigação total, em min/kg de MS e de FDN, nos animais que receberam as dietas com a silagem com farelo de mandioca podem ser explicados pela maior eficiência em ruminação observada para essa dieta.

Em estudo sobre a inclusão de 0, 10, 20 e $30 \%$ de farelo de cacau no concentrado, com proporção 50:50 volumoso: concentrado, Carvalho et al. (2008) não verificaram efeito para o tempo de mastigação total ( $\mathrm{min} / \mathrm{kg}$ de MS e FDN) em ovinos Santa Inês. Os valores observados neste estudo são superiores aos relatados por esses autores e podem ser explicados pelo menor porte dos animais, pois os animais de maior peso corporal utilizado pelos autores apresentaram maior eficiência nas atividades comportamentais, resultando em menor tempo despendido para mastigação total.

Tabela 6 - Consumo de MS e de FDN (min/kg), tempo gasto por período refeição, ruminação e ócio (min), ruminação (g de MS e FDN/ bolo), ruminação ( $\mathrm{min} / \mathrm{kg}$ de MS e FDN) e mastigação total ( $\mathrm{min} / \mathrm{kg}$ de MS e FDN) em ovinos alimentados com dietas contendo silagens de capim-elefante com diversos aditivos

\begin{tabular}{|c|c|c|c|c|c|}
\hline \multirow[t]{2}{*}{ Item } & \multicolumn{3}{|c|}{ Silagem de capim-elefante } & \multirow[t]{2}{*}{$\mathrm{CV}(\%)$} & \multirow[t]{2}{*}{ Valor-P } \\
\hline & Sem aditivo & $15 \%$ casca de café $15 \%$ farelo de cacau & $15 \%$ farelo de mandioca & & \\
\hline \multicolumn{6}{|c|}{ Consumo de MS e de FDN (min/kg) } \\
\hline Matéria seca & $456,6 \mathrm{a}$ & $365,1 \mathrm{ab}$ & $266,0 \mathrm{~b}$ & 15,4 & 0,00049 \\
\hline Fibra em detergente neutro & $947,2 \mathrm{a}$ & $742,8 \mathrm{ab}$ & $657,1 \mathrm{~b}$ & 15,6 & 0,01262 \\
\hline \multicolumn{6}{|c|}{ Períodos de refeição, ruminação e ócio (min) } \\
\hline Refeição & $50,0 \mathrm{a}$ & $37,1 \mathrm{ab}$ & $31,5 b$ & 23,9 & 0,01003 \\
\hline Ruminação & 32,1 & 25,5 & 25,0 & 17,9 & 0,12255 \\
\hline Ócio & 29,4 & 27,2 & 30,5 & 13,2 & $* * * * * * *$ \\
\hline \multicolumn{6}{|c|}{ Ruminação (g de MS e FDN/bolo) } \\
\hline Matéria seca & $1,20 \mathrm{~b}$ & $1,59 \mathrm{ab}$ & $1,86 \mathrm{a}$ & 15,5 & 0,00421 \\
\hline Fibra em detergente neutro & $0,58 b$ & $0,71 \mathrm{ab}$ & $0,75 \mathrm{a}$ & 12,5 & 0,01923 \\
\hline Matéria seca & $687,2 \mathrm{a}$ & $540,2 \mathrm{ab}$ & $445,9 b$ & 16,4 & 0,00444 \\
\hline Fibra em detergente neutro & 1424,5 & 1151,9 & 1101,8 & 14,9 & 0,09221 \\
\hline \multicolumn{6}{|c|}{ Mastigação total (min/kg de MS e FDN) } \\
\hline Matéria seca & $1144,3 \mathrm{a}$ & $846,7 \mathrm{bc}$ & $711,9 \mathrm{c}$ & 11,4 & 0,00006 \\
\hline Fibra em detergente neutro & $2371,7 \mathrm{a}$ & $1934,2 b$ & $1758,9 b$ & 10,7 & 0,00193 \\
\hline
\end{tabular}

Médias seguidas de letras iguais, na linha, não diferem entre si pelo teste Tukey a $5 \%$ de probabilidade.

$\mathrm{CV}=$ coeficiente de variação. 


\section{Conclusões}

A inclusão de farelo de mandioca na ensilagem de capim-elefante afeta positivamente alguns parâmetros do comportamento ingestivo. Dentre os aditivos casca de café e farelo de cacau, o uso de $15 \%$ de farelo de mandioca na ensilagem de capim-elefante aumenta o consumo de matéria seca e a eficiência em alimentação e ruminação em ovinos Santa Inês, o que torna esse alimento um bom aditivo na ensilagem de capim-elefante.

\section{Literatura Citada}

BERNARDINO, F.S.; GARCIA, R.; ROCHA, F.C. et al. Produção e características do efluente e composição bromatológica da silagem de capim-elefante contendo diferentes níveis de casca de café. Revista Brasileira de Zootecnia, v.34, n.6, p.2185-2291, 2005

BÜRGER, P.J.; PEREIRA, J.C.; QUEIROZ, A.C. et al. Comportamento ingestivo em bezerros holandeses alimentados com dietas contendo diferentes níveis de concentrado. Revista Brasileira de Zootecnia, v.29, n.1, p.236-242, 2000.

CARVALHO, G.G.P.; PIRES, A.J.V.; SILVA, R.R. et al. Comportamento ingestivo de ovinos alimentados com dietas compostas de silagem de capim-elefante amonizada ou não e subprodutos agroindustriais. Revista Brasileira de Zootecnia, v.35, n.4, p.1805-1812, 2006.

CARVALHO, G.G.P.; PIRES, A.J.V.; SILVA, R.R. et al. Aspectos metodológicos do comportamento ingestivo de ovinos alimentados com capim-elefante amonizado e subprodutos agroindustriais. Revista Brasileira de Zootecnia, v.36, n.4, p.1105-1112, 2007.

CARVAlhO, G.G.P.; PIRES, A.J.V.; SILVA, R.R. et al. Comportamento ingestivo de ovinos Santa Inês alimentados com dietas com farelo de cacau. Revista Brasileira de Zootecnia, v.37, n.4, p.660-665, 2008.

EVANGELISTA, A.R.; LIMA, J.A. Silagens: do cultivo ao silo. 2.ed. Lavras: Universidade Federal de Lavras, 2002. 210p.

FERRARI JR., E.; LAVEZZO, W. Qualidade da silagem de capimelefante (Pennisetum purpureum, Schum) emurchecido ou acrescido e de farelo de mandioca. Revista Brasileira de Zootecnia, v.30, n.5, p.1424-1431, 2001.

FERREIRA, A.C.H.; NEIVA, J.N.M.; RODRIGUEZ, N.M. et al. Valor nutritivo das silagens de capim-elefante com diferentes níveis de subprodutos da indústria do suco de caju. Revista Brasileira de Zootecnia, v.33, n.6, p.1380-1385, 2004

FISCHER, V. Efeito do fotoperíodo, da pressão de pastejo e da dieta sobre o comportamento ingestivo de ruminantes. : 1996. 243f. Tese (Doutorado em Zootecnia) - Universidade Federal do Rio Grande do Sul, Porto Alegre, 1996.

NATIONAL RESEARCH COUNCIL - NRC. Nutrient requirements of dairy cattle. 7.ed. Washington, D.C.: National Academy Press, 2001. 450p.

POLLI, V.A.; RESTLE, J.; SENNA, D.B. et al. Aspectos relativos à ruminação de bovinos e bubalinos em regime de confinamento. Revista Brasileira de Zootecnia, v.25, n.5, p.987-993, 1996.

RIBEIRO JR., J.I. Análises estatísticas no SAEG (Sistema para análises estatísticas). Viçosa, MG: UFV, 2001. 301p.

RODRIGUES, P.H.M.; BORGATTI, L.M.O.; GOMES, R.W. et al. Efeito da adição de níveis crescentes de polpa cítrica sobre a qualidade fermentativa e o valor nutritivo da silagem de capimelefante. Revista Brasileira de Zootecnia, v.34, n.4, p.1138-1145, 2005.

SILVA, D.J.; QUEIROZ, A.C. Análise de alimentos: métodos químicos e biológicos. Viçosa, MG: Editora UFV, 2002. 235p.

SNIFFEN, C.J.; O'CONNOR, D.J.; Van SOEST, P.J. et al. A net carbohydrate and protein system for evaluating cattle diets: carbohydrate and protein availability. Journal of Animal Science, v.70, n.12, p.3562-3577, 1992.

TEIXEIRA, R.M.A.; CAMPOS, J.M.S.; VALADARES FILHO, S.C. et al. Consumo, digestibilidade e desempenho de novilhas alimentadas com casca de café em substituição à silagem de milho. Revista Brasileira de Zootecnia, v.34, n.4, p.968-977, 2007. 